\title{
A Study of Worker Participation in Management Decision Making Within Selected Establishments in Lagos, Nigeria
}

\author{
Yusuf Noah \\ Department of Sociology, University of Ilorin, Ilorin, Nigeria \\ E-mail: noahsarkplc@yahoo.com
}

KEYWORDS Employees; democracy; involvement; attitude; work

\begin{abstract}
This paper is concerned with an investigation of the existing level of worker participation in management decision making within the Nigerian work environment. The study involved a survey in which a total of two hundred and twenty seven (217) non management employees drawn from two work organizations in Lagos (Flour Mills Nigeria Plc and Niger Insurance Plc) were used as subjects. Interview schedule and in-depth interview were the main research techniques adopted for data collection while percentage distribution and chisquare statistical techniques were used to analyze the data collected for the study. Results show that employees in both organizations demonstrate a high interest in participation in the decision making process within their respective work places. However, the actual level of involvement in management decision making demonstrated by the employees was found to be relatively low. There is significant relationship between education and employees' involvement in decision making at Flour Mills Nigeria Plc. In Niger Insurance Plc, there is a significant relationship between age and employees' involvement in decision making as well as between frequency of employees' consultation and organizational commitment. The study reveals a growing desire of non-management employees in the Nigerian work environment to exercise greater involvement in the decision making process of their enterprises.
\end{abstract}

\section{INTRODUCTION}

The concept of worker participation represents a popular theme in the analysis of the world of work among scholars in the fields of Industrial Sociology, Industrial Relations as well as management. It refers to any arrangement which is designed to involve low cadre employees (workers) in the important decision making within the workplace. This implies that rather than saddling only a group within the enterprise (for instance, management) with the responsibility of making decisions, all those who are to be affected by these decisions (including the workers) would be involved in its formulation and implementation.

In recent time, scholars have directed increasing attention to the issue of worker participation and its broader corollary, industrial democracy (Mankidy, 1984: Yesufu, 1984, Adewumi 1989; Verma and Syha; 1991, Weller 1993; Kester and Pinaud, 1996; Adu-Amankwah and Kester, 1999). These concerns reflect a growing interest in finding ways to make work more meaningful and satisfying to the workers. This rest on the belief that the organizational goals of high productivity and harmonious industrial relations are best achieved when the higher level needs of the human elements (workers) are satisfied.

Worker participation implies arrangements designed to involve workers in the enterprises decision making process. This allows for workers' involvement in the initiation, formulation and implementation of decisions within the enterprise. The concept can also be understood in terms of a new approach to industry and society in which people want to be interested with the taking of decisions which have direct bearing on them.

MacGregor (1960) contend that worker participation consists basically in creating opportunity under suitable conditions for people to influence decisions which affect them. It is a special case of delegation in which the subordinate gain greater control, greater freedom of choice with respect to bridging the communication gap between the management and the workers. This serves to create a sense of belonging among the workers as well as a conducive environment in which both the workers would voluntarily contribute to healthy industrial relations.

\section{The Problem}

The spread of democratic value to virtually every society today has brought the need to examine the implications of this trend to other spheres of life. With respect to economic sector, employees are faced with the dilemma of how to 
cope with authoritative management in the work places while living in a democratic society which guarantee basic fundamental freedom.

In addition, the denial of workers active involvement in decision making is held to be one of the major causes of the problems which are manifested daily in the work lives of the modern employees.

The implication of these to employees of increasing exposure to a monetized society, rising education and wider contact among people resulting from the break-up of artificial barriers was to shift these aspirations to a more satisfying work experience, greater control over the organization of work, greater opportunity for personal development and wider scope in exercise of initiatives.

Specifically, the refusal of work organizations to recognize the human factor in industrial production through greater involvement of employees in its management decision making would tend to create several human problems in this setting. A worker is a social being who brings his personality, hopes, aspirations, anxieties, feeling and attitude to the work place. He seeks satisfaction and meaning in his work as he does in other spheres of life. However, when he finds that his work does not provide him with the opportunity to realize his potentials (for instance, through strict management control) he tends to engage in negative behaviours like absenteeism, apathy, low commitment and low productivity. The implication of these negative tendencies resulting from strict management control has therefore raised serious concern among scholars interested in healthy industrial relations.

\section{Objectives of Study}

The central objective of the study is to determine the level of worker participation in management decision making in the Nigerian industry. The specific objective are to;

- ascertain workers level of involvement in the decision making process of their work places;

- establish the general attitude of workers towards worker participation in management decision making;

- determine factors which aid or hinder the observed level of participation; and,

- investigate the implications of worker participation to worker and their organizations.

\section{Rationale for the Study}

The rationale for the study is anchored on the need to raise the productivity level of workers through appropriate motivational techniques. The involvement of workers in management decision making is considered as a means for inducing motivation in the workers leading to positive work attitude and high productivity.

The study is also deemed desirable in view of the benefits of worker participation to organization and the society at large. Worker participation has been seen as capable of providing workers conducive work environment, opportunity to exercise their innate potentials and willingness to pursue corporate goal of the organization.

\section{Review of the Literature}

Worker participation has been explained as a plank of industrial democracy (Adewumi, 1991). Mills (1977) described the spread of industrial democracy to Western Europe in the 1970s a story of capitalism in transition. In his words, in countries where it is occurring, industrial democracy,

affects the nature, control and even ownership of private enterprise; the nature control, power and bargaining areas of the labour unions... and the roles and contributions and rights of the individual worker in contemporary and future industrial society (cited in Heisler and Houck (eds.) (1977: 116)

The description above shows that industrial democracy affects many aspects of lives of different people in modern society. This reason may explain the wide clamour for the introduction of worker participation arrangement in most countries.

Mills (1977) identified four basic forces underlying the clamour for industrial democracy. The first one was political in nature, pushed primarily by socialists and moderate labour and political leaders. The second was an industrial or economic force championed by innovative and socially-oriented management and at times, by unions. The third was an intellectual and theoretical force pushed by MacGregor (1960) Maslow (1964) and Emery, Thosrud and Trist (1964).

The last force is what Mills (1977) called the revolution of rising entitlements prominent in 
western Capitalist and democratic societies. This egalitarian spirit manifested itself in,

growing public distaste, desire and disillusionment with traditional institutions and their leadership, growing aberrant social behaviours including crime and drug abuse.

new demand for participative right of every kind including women's rights (P.122).

This fervor explains rising workers demand for increasing influence in management decision making. The increasing interest in worker participation has been traced to a number of factors. First, is the real or anticipated political pressure which was designed to extend the popular democratic dispensation in the larger society to the economic sphere. Second, is the growing pressure on the collective bargaining system arising from continuing difficulties from negotiating in the context of high inflation and in some instances increasing disenchantment with the dialogue of confrontation. More importantly, is the endemic problem within the modern industrial system which may tend to encourage employers to consider experimenting with different forms of participation. Lastly, the growing interest in participation was encouraged by the problem associated with denying powerful groups (for example, shop stewards and work groups) formal and legal means of exercising their rights. When such situation arises, the workers concerned will employ informal bargaining methods and illegitimate facts to achieve their goals. To forestall these negative trends; management is forced to introduce certain participation schemes (Mills 1997).

The industrial democracy movement can be seen therefore as part of the Quality of Work Life Movement (QWLM) which spread throughout Europe during early 1970 s. A major impetus to this movement was provided by the Workers Constitution Act Passed by the German Bundestag in 1972. The Act imposed a mandatory Worker Council on every German enterprise employing more than five employees.

In the 1990s, the industrial democracy movement took the form of what Freeman and Rogers (1993:13) called employee representation. Like worker participation and other stands of industrial democracy, employees representation connotes greater influence of workers in several aspects of the work. It also involves restructuring management to meet the new demands of efficient management, international competition, rapid technological change and changing work force expectation of work (Freeman and Rogers 1993: 111).

A related concept to employee Participation is joint Governance. The concept was developed by Verma and Cutcher-Gershanfield (1991) who defined it as:

an ongoing formal process where workers and their immediate supervisors or union and management bear joint responsibility for making decisions which may be narrow (for instance, involving a single tissue) or it may be broader covering a wide range of issues ( $P$. 200).

Joint governance would then be taking to imply statutory arrangements that are meant to provide equal decision making power to subordinate employees. However, like other programmes with similar objectives, joint governance provides little opportunity for real decision making power to employees. Wellins-Byham and Wilson (1991) argued that in some joint governance programs, workers are involved at the shop floor levels in issues relating to production and equality. However, in this instance, rarely were these workers provided with any concrete decision making power. In some of the programmes, employees were given advisory role which in few cases may confer them with an influential voice. But this is still far short of sharing decision making power which a full worker participation arrangement would imply.

Levine and Tyson (1990) distinguished between consultative and substantive forms of participation. In consultative forms, employees provide information or advice, but management retains the right to make decisions. In more substantive participatory systems workers have greater autonomous control over methods and pace of work and make decisions that substantively affect the production process. This distinction between consultative and substantive forms of participation is what Rubestein, Bennett, and Kochan, (1992) called "off-line versus "online" participation. These terms distinguish between workers who make suggestions to management through problem-solving groups off the job and workers who make decisions with respect to work tasks or quality control as part of their daily work responsibilities (Kester, Zammit, and Gold, 2002).

Studies have also focused on the effect of worker participation on organizational performance (Kelly and Harrison, 1992; Levine and 
Tyson, 1990; Lawler et.al. 1992). These studies found that participation programs have positive, or in some cases, ambiguous effect on productivity. Furthermore, employee participation and industrial relations practices may interact so that the sum of the effects on plant performance are stronger than the effects on the individual practices themselves (Cooke, 1994). Lastly, effects on productivity are expected to be greatest when the organization adopts a coherent system of work organization and industrial relations practices (Dunlop, 1958; CutcherGersenfeld, 1991; Kochan and Useem, 1992). In the view of Kester, Zammit and Gold (2002), democratic participation is no longer primarily a battleground between capital and labour, implying a win-lose game, but a common challenge, a winwin game that forces all parties to reconsider the rules of the game and the roles of the actors.

With respect to the status of worker participation in the developing world, Mankidy (1984) Kester and Schiphorst (1986) have argued that in these countries, labour relations are characterized by a break-up of existing patterns. In many of these countries, there is an increasing awareness that the labour relations produced in these countries are grossly defective. Trade unions are also seen as very weak in many of them. Lastly, on the ideological ground, collective bargaining is rejected because of its emphasis on the dependent wage labour position of the worker.

Kester and Thomas (1981) have demonstrated that there is a fast growing interest in the development of worker participation in developing countries. In their studies, they found one form of worker participation or the other in these countries. In some cases, worker participation was introduced an essential part of development strategy. For instance, in Tanzania, the idea of worker participation formed an important aspect of her socialist ideology. This is anchored on the notion of man centered development strategy.

In Nigeria, the institutionalization of worker participation within the nation's industrial relations system was championed by several scholars. Fashoyin (1992), Adewumi (1993) and Imaga (1994) have suggested that worker participation in management decision making represents a means of reducing industrial conflict, raising workers productivity and ensuring rapid socio-economic development.

Adewumi (1990:7) contended that the Nigerian Industrial relations system is guided by the underlying philosophy of industrial democracy. This implies the establishment of institutions and machineries though which management and workers meet on equal footing to discuss, consult and negotiate the terms and conditions of employment. In reiterating the principle of industrial democracy as the guiding spirit of Nigeria's industrial relations system, the National Labour Policy states;

If management must participate in decisions for determining the share of the worker from the results of the co-operative use of labour and capital, then the worker is equally entitled to participate in the decisions relating to share of capital, namely, profit and indeed all decisions hitherto arrogated to itself by the employer or management relating to the whole organization and operation of the enterprise; determining objectives and policies, the relative share of the co-operating factors of production (Yesufu, 1992: 142)

Adewumi (1993:76) argued that the only avenue for the realization of the objective of worker participation in management decision making in Nigeria is through the collective bargaining machinery. However it is evident that this machinery is very defective in Nigeria because of its restrictive nature. Consequently, such arrangement cannot confer effective participation right to the workers.

\section{Theoretical Framework}

The human relations and participatory democratic theories are adopted to guide our study on worker participation in management decision making. The human relations theory stems from the understanding that the co-operation of workers is desirable for the attain-ment of the objectives of high productivity and industrial peace. It contends that workers would be better motivated if they are treated like human beings rather than as irrational objects. For instance, by making them have a feeling that the organization accords them recognition by involving them in the decision making process. In the light of the theory, the worker is to be perceived in terms of his membership of a social group rather as an individual. Consequently, his behaviour is seen as a response to group norms rather than simply being directed by financial consideration. Workers should then be expected to react to group norms so that when they are given the opportunity to take part in 
management decision making, they are likely to respond positively to organizational issues.

The democratic participatory theory emphasizes on conditions which are necessary for effective participation and function performed by participation to the individuals and society. For instance, Rosseau (1956) contended that through participation in decision making, individual sense of freedom is increased since it gives him a very real degree of control over the course of his life and structure of his environment. Again, it serves to increase the value of individual freedom by enabling him to be his own master.

Mills (1965) sees industry as an area where the individual could gain experience in the management of the collective just as he could in government. The theory views the political arena as a kind of market place in which individuals constantly attempt to maximize the benefits, minimize losses they could secure from the political process. It assumes that man is selfish in the sense that each participant would be motivated by the desire to protect or enhance his own personal interest. The theory assumes that increase participation is likely to increase the feeling of political efficiency that ordinary citizens possess. This helps to increase the potential so that their actions can have effect on public policy and lead to a greater sense of control over their communal lives. In essence, greater participation in one sense of life leads to greater participation in other spheres i.e. the work place (Pateman, 1970)

\section{METHODOLOGY}

The study adopted the case study approach for the purpose of conducting an empirical investigation on the issue of worker participation in management decision making in the Nigerian work environment. The study was conducted between the months of October 2004 and March 2005. Main data were collected both through the primary and secondary sources. Primary sources of data were derived from the questionnaire and in-depth interview while secondary sources were got from company records, bulletins and other official documents. The adoption of these tools helped to collect both quantitative and qualitative data. The questionnaire was in three sections the first contained questions on respondents personal data, the second on the level of worker participation while the third is on worker participation structures.
The study population comprises of workers in two selected organizations in Lagos, namely; Flour Mills Nigeria Plc Apapa and Niger Insurance Plc (Headquarters), Lagos. A total of two hundred and twenty seven (227) subjects drawn from the two selected establishments constitute the sample for the study. The subjects were selected through a combination of clustering and systematic sampling methods.

\section{Hypotheses}

The following testable hypotheses were formulated to guide the attainment of the research objectives. There is a relationship between employees' socio-economic status and the level of involvement in decision making such that:

1. An employee in higher job position tends to exercise more involvement in management decision making than another in lower job position.

2. An employee who possess higher educational qualification would tend to have more influence in management decision making than other who possess lower educational qualification.

3. A young employee would more likely demonstrate more involvement in management decision making than his older counterpart.

\section{FINDINGS AND DISCUSSIONS}

As evidenced from tables 1 to 8 the demographic composition of the subjects reflects the majority are male, middle age with low educational qualification. This finding is a reflec-tion of the structure of the Nigerian Industrial labour force in which middle age male workers are more represented than their female counterpart. It also reflects on the occupational status of the subjects of the study all of whom are lower cadre workers.

Findings on respondents frequency of involvement in the decision making process of their organization as reflected in table 4 shows

Table 1: Sex distribution of respondents

\begin{tabular}{lccccc}
\hline Sex & \multicolumn{2}{l}{$\begin{array}{l}\text { Flour Mills } \\
\text { Nigeria }\end{array}$} & & \multicolumn{2}{c}{ Niger } \\
\cline { 2 - 3 } & No. & & \multicolumn{2}{c}{ Insurance } & Plc. \\
\cline { 2 - 3 } \cline { 5 - 6 } & 60 & & & No. & $\%$ \\
\hline Male & 30 & 33.4 & & 67 & 56.2 \\
Female & 90 & 100.0 & & 137 & 100.0 \\
\hline Total & 90.6 &
\end{tabular}

Source: Author's Field Work, 2004. 
that respondents in the two study organizations demonstrated generally low measure. However we found that employees in Niger Insurance have a higher frequency of involvement than those in

Table 2: Age distribution of respondents.

\begin{tabular}{lccccc}
\hline Age group & \multicolumn{2}{c}{$\begin{array}{l}\text { Flour Mills } \\
\text { Nigeria Plc. }\end{array}$} & & \multicolumn{2}{c}{$\begin{array}{c}\text { Niger } \\
\text { Insurance Plc. }\end{array}$} \\
\cline { 2 - 3 } \cline { 5 - 6 } & No. & $\%$ & & No. & $\%$ \\
\hline 30 years or less & 35 & 38.8 & & 53 & 38.7 \\
Between 30-40 years & 41 & 45.6 & & 65 & 47.4 \\
41years and above & 14 & 15.6 & & 19 & 13.9 \\
\hline Total & 90 & 100.0 & & 137 & 100.0 \\
\hline
\end{tabular}

Source: Author's Field Work, 2004.

Table 3: Respondents educational qualification.

\begin{tabular}{|c|c|c|c|c|}
\hline \multirow{3}{*}{$\begin{array}{l}\text { Educational } \\
\text { Qualification }\end{array}$} & \multicolumn{4}{|c|}{ Organisation } \\
\hline & \multicolumn{2}{|c|}{$\begin{array}{l}\text { Flour Mills } \\
\text { Nigeria Plc. }\end{array}$} & \multicolumn{2}{|c|}{$\begin{array}{c}\text { Niger } \\
\text { Insurance Plc. }\end{array}$} \\
\hline & No. & $\%$ & No. & $\%$ \\
\hline Primary Sch. Cert. & 2 & 2.2 & 6 & 4.4 \\
\hline Sch. Cert. \& Equivalent & t 38 & 42.2 & 43 & 31.4 \\
\hline OND/NCE Certificate & 30 & 33.3 & 64 & 46.7 \\
\hline First Degree & 11 & 12.2 & 16 & 11.7 \\
\hline Post Graduate & 9 & 10.0 & 8 & 5.8 \\
\hline Total & 40 & 100.0 & 137 & 100.0 \\
\hline
\end{tabular}

Source: Author's Field Work, 2004.

Table 4: Distribution of respondents by rrequency of involvement in the decision making process of the work place.

\begin{tabular}{|c|c|c|c|c|}
\hline \multirow{3}{*}{$\begin{array}{l}\text { Frequency of } \\
\text { involvement }\end{array}$} & \multicolumn{4}{|c|}{ Organisation } \\
\hline & \multicolumn{2}{|c|}{$\begin{array}{l}\text { Flour Mills } \\
\text { Nigeria Plc. }\end{array}$} & \multicolumn{2}{|c|}{$\begin{array}{c}\text { Niger } \\
\text { Insurance Plc. }\end{array}$} \\
\hline & No. & $\%$ & No. & $\%$ \\
\hline Not at all. & 25 & 27.8 & 14 & 10.2 \\
\hline Occasionally & 43 & 47.8 & 76 & 55.5 \\
\hline Often & 20 & 22.2 & 45 & 32.8 \\
\hline No Response & 2 & 2.2 & 2 & 1.5 \\
\hline Total & 90 & 100.0 & 137 & 100.0 \\
\hline
\end{tabular}

Source: Author's field work, 2004.

Table 5: Respondents involvement in the decision making in administration of social facilities.

\begin{tabular}{|c|c|c|c|c|}
\hline \multirow{3}{*}{$\begin{array}{l}\text { Frequency of } \\
\text { involvement }\end{array}$} & \multicolumn{4}{|c|}{ Organisation } \\
\hline & \multicolumn{2}{|c|}{$\begin{array}{l}\text { Flour Mills } \\
\text { Nigeria Plc. }\end{array}$} & \multicolumn{2}{|c|}{$\begin{array}{c}\text { Niger } \\
\text { Insurance Plc. }\end{array}$} \\
\hline & No. & $\%$ & No. & $\%$ \\
\hline Not at all & 38 & 42.2 & 59 & 43.0 \\
\hline Not at much & 32 & 35.6 & 54 & 39.4 \\
\hline Much & 20 & 22.2 & 24 & 17.6 \\
\hline Total & 90 & 100.0 & 137 & 100.0 \\
\hline
\end{tabular}

Source: Author's Field Work, 2004.
Flour Mills Nigeria plc. This variation could be explained by the relatively higher educational status of respondents from Niger Insurance plc. In addition in this company, there are a larger number of professionals who are more willing to seize the opportunity of participation in management decision making:

Results of in-depth interview conducted with some respondents attest to our findings. When asked about the extent to which he is involved in the making of decisions within the company, an insurance clerk in the insurance underwriting office of Niger Insurance plc. replied:

"The management in this company does not consider it as its duty to contact junior employees on how decisions are made"

A factory operator in Flour Mills of Nigeria plc has this to say on similar question:

"I am always busy in the factory, may be this is why I don't know about decision making".

It is possible to observe the obvious variation in reasons advanced by the two informants on why they demonstrated low involvement in management decision making. While the informant from Niger Insurance plc expressed that his low or lack of involvement was due to management unwillingness, the respondent from Flour Mills of Nigeria plc, indicated that he was not much involved in management decision making because of his busy schedule work.

It is also interested to know that a number of the respondents indicated that they had no interest in participating in the management decision making of their work places. This category of employees demonstrated a nonchallant attitude towards their involvement in the management decision making. As a respondent in Flour Mills of Nigeria plc says:

"I am in this company to work and earn my salary. I have no business with decision making. I am not paid for such job."

An opinion like this reflects the instrumental orientation of some of the workers in the two study establishments. Being mostly junior workers, these respondents tend to demonstrate more interest in earning a living from work rather than to satisfy the higher order needs of self expression through participation.

However, in spite of this tendency, our findings show that a substantial proportion of respondents in both study organizations reported that they are involved either regularly or occasionally in the management decision 
Table 6: Relationship between respondents educational level and involvement in management decision making.

\begin{tabular}{|c|c|c|c|c|c|}
\hline \multirow[t]{2}{*}{ Organization } & \multirow{2}{*}{$\begin{array}{l}\text { Educational } \\
\text { Level }\end{array}$} & \multicolumn{4}{|c|}{ Involvement in decision making } \\
\hline & & None & Occasionally & Often & Total \\
\hline \multirow[t]{4}{*}{ Flour Mills Nig. plc. } & Low & $6(50 \%)$ & $4(33.3 \%)$ & $2(16.6 \%)$ & $129(100 \%)$ \\
\hline & Moderate & $7(10.3 \%)$ & $34(50 \%)$ & $27(9.7)$ & $68(100 \%)$ \\
\hline & High & $1(5 \%)$ & $5(25 \%)$ & $14(70 \%)$ & $20(100 \%)$ \\
\hline & Sub-Total & $14(15.6 \%)$ & $43(47.8 \%)$ & $33(36.7 \%)$ & $90(100 \%)$ \\
\hline \multicolumn{6}{|c|}{$\chi^{2}=14.77 ;$ d.f. $=4 ; \mathrm{p}<.05$} \\
\hline \multirow{4}{*}{ Niger Ins. Plc. } & Low & $4(18.2 \%)$ & $14(63.6 \%)$ & $4(18.2 \%)$ & $22(100 \%)$ \\
\hline & Moderate & $10(9.4 \%)$ & $57(53.8 \%)$ & $(36.80 \%)$ & $106(100 \%)$ \\
\hline & High & $2(22.2 \%)$ & $5(55.6 \%)$ & $2(22.2 \%)$ & $9(100 \%)$ \\
\hline & Sub-Total & $16(11.7 \%)$ & $76(53.5 \%)$ & $45(32.8 \%)$ & $137(100 \%)$ \\
\hline
\end{tabular}

$\chi^{2}=3.74$, d.f. $4 ; \mathrm{P}>.05$

Table 7: Relationship between respondents age and involvement in management decision making

\begin{tabular}{|c|c|c|c|c|c|}
\hline \multirow[t]{2}{*}{ Organization } & \multirow[t]{2}{*}{ Age group } & \multicolumn{4}{|c|}{ Involvement in Decision making } \\
\hline & & None & Occasionally & Often & Total \\
\hline \multirow[t]{4}{*}{ Flour Mills Nig. plc. } & $30 y r s$ or less & $6(17.1 \%)$ & $21(60) \%$ & $8(22)$ & $35(100 \%)$ \\
\hline & $31-40$ yrs & $4(10 \%)$ & $18(45) \%$ & $18(45 \%)$ & $40(100 \%)$ \\
\hline & $41 y r s \&$ above & $3(21.4 \%)$ & $4(28.6 \%)$ & $7(50 \%)$ & $14(100 \%)$ \\
\hline & Sub-Total & $13(14.6 \%)$ & $43(48.3 \%)$ & $33(37.1 \%)$ & $89(100 \%)$ \\
\hline \multicolumn{6}{|c|}{$\overline{\chi^{2}=6.6 ; \text { d.f. }=4 ; p<.05}$} \\
\hline \multirow[t]{4}{*}{ Niger Ins. Plc. } & 30 yrs or less & $4(18.2 \%)$ & $27(51.9 \%)$ & $16(30.8 \%)$ & $52(100 \%)$ \\
\hline & $31-40$ yrs & $10(9.4 \%)$ & $42(64.6)$ & $17(26.2 \%)$ & $65(100 \%)$ \\
\hline & 41 yrs and above & 0 & $2(36.8 \%)$ & $12(63.2 \%)$ & $14(100 \%)$ \\
\hline & Sub-Total & $15(11.1 \%)$ & $76(53.5 \%)$ & $-33.12 \%$ & $136(100 \%)$ \\
\hline
\end{tabular}

$\chi^{2}=6.61 ;$ d.f. $=4 ; \mathrm{P}<.05$.

Table 8: Relationship between respondents job position and involvement in management decision making.

\begin{tabular}{llrrrr}
\hline Job Position & & \multicolumn{3}{c}{ Involvement in Decision making } \\
\cline { 3 - 6 } & & Not at all & Occasionally & Often & Total \\
\hline Flour Mills Nig. plc. & Low cadre & $8(21.6 \%)$ & $20(54.1 \%)$ & $9(24.3 \%)$ & $37(100 \%)$ \\
& Middle cadre & $3(7.5 \%)$ & $16(40 \%)$ & $21(52.5 \%)$ & $40(100 \%)$ \\
& High cadre & $1(16.7 \%)$ & $3(50 \%)$ & $2(33.3 \%)$ & $6(100 \%)$ \\
\hline & Sub-Total= & $12(14.5 \%)$ & $39(47.0 \%)$ & $32(38.5 \%)$ & $83(100 \%)$ \\
\hline$\chi^{2}=7.5 ;$ d.f. $=4 . p$ p $<.05$. & & & & \\
Niger Ins. Plc. & Low cadre & $8(16.0 \%)$ & $30(60 \%)$ & $12(24 \%)$ & $50(100 \%)$ \\
& Middle cadre & $5(6.4)$ & $43(55 . \%)$ & $30(85.5 \%)$ & $78(100 \%)$ \\
& High cadre & 0 & $1(33.3 \%)$ & $2(66.7 \%)$ & $3(100 \%)$ \\
\hline & Sub-Total= & $13(9.9 \%)$ & $74(56.5 \%)$ & $44(33.6 \%)$ & $137(100 \%)$ \\
\hline
\end{tabular}

$\chi^{2}=6.54 ;$ d.f. $=4 ; \mathrm{P}>$. 05 .

making process of their companies. In the words of a respondent in Niger Insurance plc:

"Management in this company does not hesitate to involve some of us in the decision making process whenever it is necessary"

This opinion is similar to another expressed by a Foreman in Flour Mills of Nigeria plc:

"As a senior staff, I and other Foreman in the various units are made to contribute to the decisions in matter relevant to our department"
Views like the one above shows that respondents have some measures of involvement in the decision making process of their organization.

On the factors which could influence employee involvement in management decision making. Tables 4 to 8 show the relationship between age, education and job position and respondents level of involvement. As shown in table 6 above, there is a statistically significant relationship between respondents educational 
attainment and their involvement in management decision making in Flour Mills of Nigeria plc while such relationship was absent in Niger Insurance. This finding demonstrates that respondents' measures of involvement are related to their educational qualification in Flour Mills of Nigeria plc. In this company, while those who possess low educational qualification exercise low measure of involvement, those with higher education demonstrated equivalent level of involvement in management decision making.

It is evidenced from these findings that an individual's educational qualification could influence the level of involvement he could exercise. This finding is not surprising since those with higher educational qualification tend to have more knowledge about management decision making and are also more likely to seize the opportunity to be involved in the affairs of their organizations.

\section{CONCLUSION AND RECOMMENDATIONS}

Based on the findings of the study it could be concluded that workers in the study establishments are generally not much involved in the management decision making within their respective establishments. On the other hand, the workers generally demonstrated high interest in management decision making. The study therefore confirmed that while the workers demonstrated positive attitude towards involvement in decision making, the actual level of involvement they exercise is negative. However, we found that workers in Niger Insurance plc. demonstrated more involvement in management decision making more than their counterparts in Flour Mills of Nigeria plc. This implies that workers in the service sector are more involved in management decision making than those in the Manufacturing sector of the Nigerian economy.

Workers who are subjects of this study generally demonstrated willingness to accept the responsibility of involvement in management decision making whenever such opportunity arises. However many hold the view that management decision making is the preserve of the management. This implies that while the workers are willing to accept the responsibility of greater involvement in management decision making they are not ready to challenge the management in this regard.
Another conclusion reached from the study is that respondent's level of income in management decision making have implication on certain organizational factors. Specifically, the commitment level demonstrated by the workers is a factor of the extent of influence they exercise in management decision making.

Finally, from the respondents' assessment of management attitude towards workers participation, it could be concluded that the management in the Nigerian work enterprises are not favorably disposed towards granting workers significant measure of involvement in management decision making. This finding would lead us to conclude that a lot needed to be done to change the current negative disposition of the Nigerian management towards workers involvement in management decision making. More importantly, the current obstacles against effective workers participation in Nigeria could be tackled through;

- Enlightenment program for workers on their rights to seize the opportunity of involvement in decision making.

- Provision of monetary and other incentives for workers to encourage them sustain the current interest in participation.

- Liberalizing management structure so as to allow for greater workers involvement, and lastly,

- training programmes for workers in management functions as a way of properly equipping them on their decision making role.

\section{REFERENCES}

Adu-Amankwah, K. and G. Kester. (Eds.) 1999. How to Make Democratic Participation a Success: An Africasn Trade Union Challenge. Rotterdam: Textua.

Adewumi, F. 1993. "Industrial Relations Economic Development and Democracy: A Preliminary Note", (Pp. 59-82) in E.F. Osuji (ed.), Challenges Facing Industrial Relation in Nigeria in the Context of Emerging New Economic and Political Order. Department of Adult Education University of Ibadan, Ibadan. Nigeria

Cutcher-Gershenfeld, J. 1991. "Recent Developments in U.S. Employee Involvement Initiatives: Erosion or Diffusion", (Pp. 1-32) in D. Sockell et al. (eds.), Advances in Industrial and Labour Relations. CT: JAI Press.

Dunlop, J. 1958. Industrial Relations System. New York: Holt.

Fashoyin, T. 1992. Industrial Relations and African Development. New Delhi: South Asian Publishing Ltd.

Freeman, R.B and J. Rogers.. 1993. "Who speaks for 
us? Employee Representation in a non-union Labour Market", (Pp. 13-80) in B.B Kaufman and M.M Kleiner (eds.), Employee Representation: Alternative and Future Directions. IRRA Series.

Imaga, E.U. 1994. Industrial Democracy in the Third World: A Study of Nigeria and India, New Delhi South Asian Publishers.

Heisler, W.Y. and J. W. Hucks. 1977. A Matter of Dignity: Inquires into the Humanization of Work Notre Dam London: University of Notre Dam.

Kelley, M.R. and B. Harrison. 1992. "Unions, Technology and Labour Management co-operation", in L. Mishel and P.B. Voos (eds.), Unions and Economic Competitiveness. Armonk N.Y.: M.E. Sharpe.

Kester, G. and H. Pinaud. (Eds.) 1996. Trade Unions and democratic Participation in Europe. Aldershot: Avebury Press.

Kester, G. and F. Schiphorst. 1986. Workers Participation, Trade Union Policy and Development. The Hague: Institute of Social Studies.

Kester, G. and I. Thomas.1981. Industrial Democracy and Development. The Hague: Institute of Social Studies.

Kester, G., Zammit, E. and Gold, M. 2002. "New Frontiers of Democratic Participation at Work." Paper delivered at the $11^{\text {th }}$ Conference of the International Association for the Economics of Participation (IAFEP, Catholic University of Brussels, 4-6 July).

Levine, D. and L. Tyson. 1990. "Participation, productivity and the firm's Environment", in A.
Blinder (ed.), Paying for Productivity: A Look at the Evidence. Washington D.C: Brooklings Institute. MacGregor, D. 1960. The Human Side of Enterprises. New York; Mcgraw Hill.

Mankidy, J. 1984. "Employee Involved decision making in India: Retrospect and Prospect." Labour and Society, 3: 239-242.

Mills, T. 1977. "Leadership from Abroad: European Development in Industrial Democracy", in W.D. Hesler and J.W. Houks (eds.), A Matter of Dignity Inquires into the Humanization of Work. London. University of Notre dam Press.

Maslow, A.H.1964. Motivation and Personality. New York: Harper and Row.

Pateman, C. 1970. Participation and Democratic Theory. New York; Cambridge University Press.

Rosseau, J.J. 1956. The Social Contract. London; Penguin Books.

Verma, R.K. and P. R. Syha. 1991. Workers Participation in Management. New Delhi: Oxford Publication Co.

Weiler, P.C. 1993. "Governing the workplace: Employee Representation in the eyes of the Law", (Pp. 81-96) in B.E. Kaufman and M.M. Kleiner (eds.), Employee Representative: Alternative And Future Directions IRRA- Research Association Series

Wellins, R.S., W. C. Byham and J. M. Wilson. 1991. Empowered Teams. San Francisco: Josseo-Bass.

Yesufu, T.M. 1984. The Dynamic of Industrial Relations: The Nigerian Experience. Ibadan: Ibadan University Press. 